\title{
MEMBACA NILAI KEMANUSIAAN DALAM NOVEL AUTOBIOGRAFI
}

\author{
Suminto A. Sayuti, Wiyatmi, dan Dwi Budiyanto \\ Universitas NegeriYogyakarta \\ email: suminto_sayuti@uny.ac.id
}

\begin{abstract}
(Title: Reading the Value of Humanity in Novel Autobiography).This article aims at revealing and elaborating the values of humanity embedded in the authobiography novels by Indonesian writers. The study is rooted in the fact that authobigraphy novels are currently burgeoning in Indonesia. Four novels selected for this study are Kenangkenangan Hidup (Hamka), Habibie-Ainun (B.J. Habibie), Kehilangan Mestika (Hamidah), and Manusia Bebas (Soewarsih Djojopuspito). From the authobiography novels, readers, young generation in particular, can learn the values of life that the authors make as their vision to live life and its creativity processes, which cannot be separated from historical, social and political contexts. Through their authobiography novels, the authors express not only their conscience, emotion, and ideas, but also the ideology that they hold to live life and to realize their vision in the future.
\end{abstract}

Key word: authobiography, humanity, creativity processes

\section{PENDAHULUAN}

Novel autobiografi merupakan salah satu genre novel yang telah mengalami perkembangan yang cukup menggembirakan dalam tradisi sastra Indonesia. Novel yang mengangkat cerita dari perjalanan hidup penulisnya ini dapat dikatakan telah lahir sejak awal pertumbuhan novel Indonesia. Novel Kehilangan Mestika yang ditulis oleh Hamidah (1935), misalnya bahkan menggunakan nama Hamidah untuk tokoh utamanya. Diduga kisah tokoh Hamidah dalam novel tersebut merupakan catatan kisah hidup penulisnya. Sejumlah novel Indonesia yang secara karakteristik memiliki kecenderungan genre autobiografi, antara lain Manusia Bebas (Soewarsih Djojopuspito), Dari Ngalian ke Sendowo (Nh. Dini), Pengakuan Eks Parasit Lajang dan Simple Mirache (Ayu Utami), Kenang-kenangan Hidup (Hamka), Aku dan Surabaya (Gerson Poyk), Ainun-Habibie (B.J. Habibie), Laskar Pelangi dan Sang Pemimpi (Andrea Hirata), Negeri 5 Menara (Ahmad Fuadi). Walapun sering kali ada perbedaan nama tokoh dengan nama penulisnya sebagai genre autobiografi cerita yang terdapat dalam novel-novel tersebut memiliki kemiripan dengan biografi penulisnya.

Autobiografi adalah salah satu genre novel yang ditulis oleh pengarang untuk meng- gambarkan kehidupan dirinya, dan khususnya tentang perkembangan personatitasnya (Anderson, 2001:2). Secara sederhana autobiografi menunjuk pada sebuah novel yang ditulis oleh sastrawan untuk menggambarkan perjalanan kehidupan pribadinya, termasuk wilayah psikologisya, berupa perasaan, pikiran, keyakinan, dan ideologi yang dianutnya. Dengan demikian, novel autobiografi pada dasarnya novel yang mengambil sumber penciptaan dari pengalaman batiniah sang penulis. Melalui novel autobiografi seorang penulis mencoba untuk mengekspresikan sduara batinnya, emosi, perasaan, pikiran-pikirannya, bahkan juga ideologi (kesadaran kolektif) yang dihayatinya.

Meskipun memiliki kemiripan, autobiografi berbeda dengan memoar dan biografi. Memoir lebih banyak menggambarkan mengambarkan catatan berbagai peristiwa sejarah atau kemasyarakatan yang terjadi di luar pengarang (Winslow, 1995:39). Autobiografi lebih menyingkap aspek kedalaman atau psikologi pengarangnya atau pengembaraan pengarang ke dalam dirinya. Dengan demikian, bila dibandingkan dengan autobiografi, memoir kurang bersifat pribadi dan lebih ke latar belakang sejarah dan sosial. Sementara itu, perbedaan antara autobiografi dengan biografi 
terletak pada penulisnya. Biografi adalah kisah kehidupan seorang tokoh, biasanya tokoh historis yang ditulis oleh orang lain. Autobiografi, ditulis oleh diri penulis sendiri. Ainun-Habibie merupakan contoh novel autobiografi yang ditulis oleh B.J. Habibie, Panggil Aku Kartini Saja merupakan contoh biografi Kartini yang ditulis oleh Pramudya Ananta Toer. Dalam Semesta Cinta (Memoar Perempuan Penulis Indonesia) karya Pipit Senja merupakan contoh memoar.

Walaupun sejumlah novel tersebut pada umumnya telah banyak dikaji dengan berbagai fokus masalah dan perspektif, namun relatif jarang dipahami dalam perspektif novel autobiografis. Padahal kalau dipahami dalam hubungannya dengan penulisnya hampir semua novel tersebut tampaknya ditulis mengekspresikan diri dan gagasan atau ideologi penulisnya.Penelitian yang dilakukan Wiyatmi (2013) terhadap Manusia Bebas karya Soewarsih Djojopuspito, misalnya tidak memandang novel tersebut sebagai novel autobiografis, tetapi dipandang sebagai novel realis yang mengusung ideologi feminisme. Dari penelitian tersebut tampak bahwa ketika sebuah novel dipahami sebagai novel realis, maka pemaknaan terhadap kisah (narasi) yang diangkat dalam novel tersebut tentu berbeda dengan ketika novel tersebut dipahami sebagai genre autobiografis. Dengan perspektif novel realis, kajian terhadap Manusia Bebas yang dilakukan Wiyatmi, sampai pada kesimpulan bahwa novel tersebut menggambarkan perjuangan kaum perempuan di Indonesia di bidang pendidikan, tanpa menghubungkan dengan kehidupan dan ideologi sastrawan penulisnya.

Berdasarkan latar belakang tersebut, maka makalah ini mencoba membahas sejumlah novel autobiografi dalam sastra Indonesia untuk memahami nilai-nilai kehidupan dan ideologi sastrawan dari karya sastra yang ditulisnya. Melalui kajian dengan perspektif psikologi pengarang diharapkan dapat dipahami eksistensi novel autobiografi sebagai sarana untuk mengekspresikan nilai-nilai kehidupan yang terintegrasi dari perjalanan hidup, emosi, pemikiran, dan ideologi yang dianut sastrawan. Psikologi pengarang merupakan salah satu kajian dalam penelitian atau kritik sastra memfokuskan perhatian pada aspek kejiwaan pengarang sebagai suatu tipe maupun pribadi (Wellek \& Warren, 1990:90).

Wellek dan Warren (1990:90) mengemukakan bahwa psikologi pengarang merupakan salah satu wilayah kajian psikologi sastra. Selain psikologi pengarang psikologi sastra juga mengkaji karya sastra dengan menggunakan perspektif psikologi, yang lebih dikenal debagai psikologi karya sastra. Selain itu juga ada psikologi pembaca, yang mengkaji hubungan antara karya sastra dengan pembaca (audience), teruasuk dampak karya sastra pada psikologi pembaca. Psikologi pengarang mencoba memahami keadaan jiwa sebagai salah satu sumber penciptaan karyanya (Hardjana, 1984:62). Melalui psikologi pengarang akan digali menggambarkan perjalanan kehidupan pribadinya, termasuk wilayah psikologisya, berupa perasaan, pikiran, keyakinan, dan ideologi yang dianutnya.

Dalam paradigma teori dan pendekatan dalam kritik sastra yang dikemukakan Abrams (1976:79) psikologi pengarang termasuk dalam pendekatan ekspresif. Dengan mengutip pendapat Longinus, Abrams (1976:75) menyatakan bahwa emosi dan passion merupakan syarat mutlak dan penting untuk menciptakan karya seni yanga agung. Emosi dan passion lebih mudah terbaca dalam genre fiksi autobiograsi dan puisi lirik. Oleh karena itu, dalam penelitian ini untuk memahami perjalanan hidup dan ideologi sastrawan dalam novel autobiografi akan digunakan pendekatan psikologi sastra.

\section{METODE}

Untuk mengkaji nilai-nilai kemanusiaan yang diekspresikan dalam novel-novel autobiografidalam sastra Indonesia digunakan metode deskriptif kualitatif engan perspektif psikologi pengarang. Sejumlah novel yang dijadikan sumber dalam kajian ini adalah Kenang-kenangan Hidup (Hamka), Kehilangan Mestika (Hamidah), Ainun-Habibie (B.J. Habibie), Manusia Bebas (Soewarsih Djojopuspito).

\section{HASIL DAN PEMBAHASAN}

Dari empat judul novel yang dipilih sebagai sampel dalam kajian ini, terungkap nilai 
kehidupan yang menjiwai karya autobiografi tersebut yaitu religiositas, cinta, nasionalisme, dan emansipasi. Religiositas, cinta, dan nasionalisme terdapat dalam keempat novel, semantara emansipasi, terdapat dalam dua novel karya sastarawan perempuan.

Kenang-kenangan Hidup karya Hamka (Prof. Dr. H. Abdul Malik Karim Amrullah atau Hamka, 17 Februari 1908 - 24 Juli 1981) menggambarkan kisah hisupnya sejak masa kanak-kanak smpai dewasa. Dari novel tersebut teruangkap pribadi dan pandangan Hamka tentang religiositas, cinta, dan nasionalisme. Hamka tidak hanya dikenal sebagai seorang ulama, tetapi sekaligus ia seorang sastrawan. Tokoh yang lahir di Sungai Batang, Tanjung Raya, Maninjau, Sumatra Barat ini telah melahirkan banyak karya dengan banyak topik dan dalam banyak bentuk. Hamka mengungkit tajuk rencana ringkas tajam, kolom nasihat untuk pembaca majalahnya, esai sejarah, filsafat, teologi, novel dan cerpen, kisah perjalanan, hingga anekdot pribadi (Rush, 2017: xxxvi). Dalam penelitian James R Rush (2017), Hamka mengungkapkan seluruh dunia sebagaimana dialami dan diharapkannya. Tidak mengherankan jika Syafi'i Ma'arif (dalam Rush, 2017: x) menyatakan bahwa lima kualitas, sebagai pengarang, pemikir, sastrawan, sejarawan publik, dan mufasir, menyatu dalam pribadi Hamka seperti yang dapat ditelusuri dari berbagai karya tulis dan ceramahnya.

Hamka memulai karier sastrawan dari novelet Si Sabariyah, kisah dalam gaya dongeng tradisional Minangkabau, kaba. Inilah satu-satunya karya Hamka yang berbahasa Minangkabau dan beraksara Arab Jawi. Disusul dengan Di Bawah Lindungan Ka'bah (1936), Tenggelamnya Kapal Van der Wijk (1939), Di Bawah Lembah Kehidupan (1939), Tuan Direktur (1939), Dijemput Mamaknya (1939), dan Merantau ke Dili (1940). Di antara kisahkisah yang dianggitnya, Kenang-kenangan Hidup merupakan bentuk autobiografi Hamka dengan gaya bertutur yang khas, yang terbit pertamakali pada 1951. Karya ini terdiri dari empat jilid. Jilid pertama berkisah tentang masa kanak-kanak Hamka yang penuh kenakalan, kehidupan di surau sebagai sistem khas budaya Minangkabau, ketegangannya dengan
Sang Ayah, perkenalannya dengan sastra serta berbagai bacaan, penjelajahannya ke Jawa, hingga keberangkatannya ke Makkah. Jilid pertama dipungkasi dengan sekelumit kisah menuju pernikahannya pada 1929. Jilid kedua mengisahkan tentang dunia kepengarangannya. Hamka paparkan awal keterlibatannya dalam "medan karang-mengarang" sebagai pemuda "didikan surau" setelah berpuluh tahun ditinggalkan zaman, sejak hilangnya Hamzah Fansuri (Hamka, 2015: 7).

Jilid ketiga mengisahkan keterlibatan Hamka di Medan pada kurun 1942-1945. Medan saat itu, seperti dijelaskan Rush (2017: 1) merupakan kawasan agrobisnis yang ramai dengan penduduk 1,5 juta. Kota yang sedang tumbuh ini hanya kalah dari Batavia dalam hal penerbitan. Di kota inilah Hamka mengelola Pedoman Masjarakat sejak 1936. Pada jilid ketiga ini pula Hamka menuturkan kedekatannya dengan penguasa Jepang, yang menimbulkan kontroversial, dan diakhiri dengan runtuhnya kekuasaan Jepang. Jilid keempat mengisahkan kiprah Hamka sejak seputar proklamasi kemerdekaan Republik Indonesia hingga agresi militer Belanda.

Sebagai sebuah autobiografi Kenangkenangan Hidup dianggit dengan sudut penceritaan bergantian. Kadangkala menggunakan sudut penceritaan orang pertama. Cara ini dilakukan Hamka saat mengisahkan masa kelahirannya. Akan tetapi, setelah itu Hamka menggunakan orang ketiga tunggal dan tidak menggunakan sudut pandang orang pertama, sebagaimana sebuah autobiografi. Pada bagianbagian tertentu Hamka seakan mengambil jarak dengan dirinya, sehingga ia menjadi lebih leluasa untuk bertutur. Sesekali ia menggunakan anak itu, lain kali Hamka gunakan teman kita untuk menggambarkan dirinya sendiri. Pada Kenang-kenangan Hidup jilid dua, Hamka gunakan Bung Haji kita untuk menyebut dirinya. Dengan cara demikian, Hamka terasa lebih leluasa untuk mengekspresikan jiwa pemberontakannya.

Lahir di tengah alam Minangkabau dan kultur keislaman yang kental, Malik - demikian panggilan Hamka di masa kecil - tumbuh dalam tradisi religiusitas yang ketat. Dari Kenang- kenangan Hidup yang dianggitnya, 
terbaca bahwa ada dua hal yang sangat mempengaruhi konstruksi nilai, idelogi, dan pandangan hidup Hamka.Dua hal itu adalah surau dan rantau (luar alam Minangkabau). Yang pertama, memperlihatkan bahwa Hamka dibesarkan dalam budaya dan jaringan keislaman yang kuat. Ayahnya, Dr. H. Abdul Karim Amrullah (Haji Rasul) adalah tokoh gerakan reformis Islam yang terkenal. Dari ayahnya dan orang-orang lain, Hamka meresapi kebutuhan untuk menggerakkan Islam demi membentuk masyarakat Muslim modern, khususnya masyarakat Indonesia modern (Rush, 2017: xxxiv), meski hubungan. Di suraulah Hamka mengenal Islam secara lebih intensif, dalam kultur Minangkabau yang terjalin relasi antara agama dan adat, seperti terungkap dalam formulasi sistem adat "adat bersendi syara', syara' bersendi kitabullah." Surau, yang semula hanya sebagai tempat bertemu, berkumpul, berapat, dan tempat tidur bagi anak laki-laki mengalami perluasan fungsi menjadi asrama anak-anak muda, tempat belajar mengaji Al-Quran, belajar agama, tempat suluk, tempat berkasidah/bergambus dan sebagainya (Azra, 2017: xix). Dalam sistem pendidikan awal seperti inilah, Hamka mengidentifikasi dirinya sebagai "pemuda didikan surau" (Hamka, 2015b: 7).

Hamka kecil adalah anak yang berjarak dan bersitegang dengan ayahnya, tapi belakangan dia sangat bangga pada ayahnya itu. Berjarak karena tidak saja karena kesibukan ayahnya sebagai pendakwah dan tokoh, tetapi sekaligus karena kecenderungan sikapnya yang "keras" mempengaruhi pula dalam mendidik anaknya (Hamka, 2015a: 19). Bersitegang bersebab ada beberapa pandangan yang tidak bertemu antara Hamka dengan ayahnya. Sang Ayah ingin anaknya menjadi ulama, seperti dirinya. Sementara, persentuhan Hamka dengan Mamak dan Andungnya mengantarkannya untuk mencintai sastra.

Setengah marah tetapi tidak marah betul, ayahnya berkata: "Apakah engkau akan menjadi orang alim nanti ini, atau akan jadi tukang cerita?"

Diletakkannya buku itu sebentar, tetapi bila ayahnya pergi, dibacanya pula. (Hamka, 2015a: 57).
Sikap ayahnya yang keras terhadap sastra kelak akan melunak setelah Hamka menerbitkan Si Sabariyah yang ditulisnya dalam Bahasa Minangkabau dengan Bahasa Arab Jawi (Hamka, 2015b: 10). Pada 1931 di hadapan ayahnya, Hamka menegaskan sikap dan keputusannya dalam bersastra.

Dengan senyum dia menjawab, "Biarlah, Ayah menjadi ulama besar. Dan doakanlah anakanda menjadi pujangga besar! Tetapi di dalam jiwa anakanda, tetaplah Islam yang berdiri!"(Hamka, 2015b: 25).

Tentu saja pilihannya sebagai sastrawan haruslah menanggung banyak tribulasi dan penentangan. Dalam Kenang-kenangan Hidup jilid dua, Hamka menuturkan bahwa sebelumnya golongan kiai pada pandangan masyarakat Islam tidak boleh menulis roman dan filsafat. Mereka hanya boleh membahas fikih. Itulah sebabnya, begitu Hamka menulis novel, pernah ia digelari orang sebagai "Kiai Cabul". (Hamka, 2015b: 42). Namun, Hamka tidak bergeming. Dalam keyakinannya tidak ada yang menghalanginya dalam bersastra, kecuali dari tradisi dan sikap fanatik.

Keseluruhan sikap dan kesadarannya tersebut tidak hanya terbentuk dari tempaan surau tetapi juga dari rantau. Pengembaraannya ke Jawa dan pertemuannya dengan HOS. Cokroaminto, Ki Bagus Hadikusumo, Sutan Masyur, dan sebagainya telah memperluas cara pandang dalam dirinya.

Syukurlah, karena di permulaan jalan, ayahnya telah membawanya ke dalam kehidupan agama, dan gurunya, Cokroaminoto telah menunjukkan jalan ke dalam mengkhidmat bangsa. Lantaran itu, dia tidak kehilangan tempat berdiri.(Hamka, 2015b:45).

Itulah sebabnya, Hamka merumuskan dasar kepengarangan dan keseniannya adalah cinta (Hamka, 2015b: 107). Cinta yang dirumuskan Hamka adalah cinta alturistik, yang memberikan daya dan harapan bagi hidup. Dari pandangan demikianlah, ia menyadari posisinya sebagai seorang sastrawan. Seniman, bagi Hamka (2015b: 120), adalah kepala pemberon- 
tak, penumbang kekuasaan yang lama, perintis jalan baru, pemuja alam dan pengabdi Tuhan. Untuk itulah pengarang harus mengatasi zamannya (2015b: 89). Keseluruhan pandangan hidupnya itu dituangkan dalam karya-karya yang dianggitnya.

Pandangannya tentang adat, tentang pembangunan kebudayaan Indonesia baru, yang tidak hanya terlingkung dalam daerah sempitnya, rasa jengkelnya atas kesempitan paham orang negerinya. Semuanya bertemu dalam buku-bukunya Tenggelamnya Kapal Van der Wijck, Merantau ke Deli, dan beberapa buah cerita pendek! (Hamka, 2015b: 65).

Di tangan Hamka, seperti diungkap Rush (2017: 252), kebijakan orang-orang masa lalu, wahyu yang diterima Nabi Muhammad, gagasan-gagasan al-Ghazali, Ibnu Rusyd, dan Muhammad Abduh, dan gelora sejarah yang mendatangkan Belanda, mesin modern, kereta api, dan pelabuhan ke Sumatera, Jawa, dan seluruh kepulauan Nusantara - semua dihubungkan dengan pembaharuan Islam modern di Hindia, nasionalisme dan pendirian Indonesia, juga kehidupan Hamka sendiri. Dengan demikian, Hamka merupakan perwujudan dari ekspresi iman yang luas, lentur, moderat, dan estetik, dengan mengusung cinta alturistik yang memberi daya hidup dan harapan bagi sesama dan kehidupan.

Sebagaimana Hamka dengan Kenangkenangan Hidup-nya, autobiografi BJ Habibie berjudul Habibie \& Ainun (2010) ternyata mengusung pandangan yang sama, yaitu cinta. Autobiografi yang dianggit presiden ketiga RI itu dipersembahkan untuk istri tercintanya: Hasri Ainun Habibie yang - menurut Habibie - jiwa, roh, batin, dan nuraninya manunggal di mana pun mereka berada di sepanjang masa. Novel ini ditulis bebrapa bulan setelah mantan presiden RI ini kehilangan istri tercintanya. Novel ini berkisah mengenai pertemuan Habibie yang sedang berlibur dari studinya di Jerman, dengan Ainun, sampai akhirnya mereka menikah dan tinggal Jerman untuk melanjutkan studinya. Dari novel tersebut juga terungkap nilai religiogitas dan nasionalisme yang selalu menuntun setiap langkah, sehingga Habibie memilih tetap kembali ke Pangkungan Pertiwi dan menolak berbagai tawaran pekerjaan di Jerman.

Seakan Habibie melalui autobiografinya, hendak menuturkan bahwa karena cintalah segala sesuatu mengabadi.Namun, sebagaimana pada Hamka, cinta itu tak bisa lepas dari pengaruh iman.

Saya menjawab: "Senyuman manis dan pandangan matamu yang selalu memukau dan merindu." Ainun segera menjawab: "Itu sudah milikmu dan kuberikan untukmu sepanjang masa sejak malam takbiran tanggal 7 Maret yang lalu." Melihat mata saya Ainun berkata: "Supaya kamu tidak terlalu lama menerka, saya sampaikan saja. Yang kamu berikan kepada saya adalah titipan Allah untuk kami berdua. Saya mengandung bayimu, anakmu, dan keturunanmu! Itu yang paling indah dan titipan Allah itu harus kami syukuri!" Saya memeluknya sambal memanjatkan doa bersama membaca al Fatihah.(Habibie, 2010: 20).

Lagi-lagi, cinta altruistik itu memberi daya untuk lebih bersemangat melakoni hidup. Begitulah sepanjang membaca Habibie \& Ainun, cinta itu tergambar memberikan penguatan hati dalam menghadapi perjuangan. Habibie merasa tersemangati, termotivasi, dan terilhami Ainun, istrinya.Akibatnya, produktivitas kerja Habibie terus meningkat (Habibie, 2010: 33). Tidak sekedar itu, cinta Habibie \& Ainun ternyata selalu terbingkai semangat nasionalisme yang kental. Seusai memberi kuliah umum pada 15 Juli 1965, Habibie mendapat banyak tawaran kerja dari beberapa negara, salah satunya adalah perusahaan Amerika Boeing. Tawaran tersebut menciptakan kondisi dilematis dalam diri pasangan muda itu.

Diskusi saya dengan Ainun mengenai masa depan kami dan pembangunan Indonesia sangat mendalam dan lebih susah memutuskan dibandingkan dengan tawaran Professor Ebner. Bukankah yang ditawarkan oleh Boeing adalah pekerjaan di industri? (Habibie, 2010: 41).

Membaca Nilai Kemanusiaan ... (Suminto A. Sayuti, Wiyatmi, dan Dwi Budiyanto) 
Tawaran menggiurkan itu ditolak karena Ainun mengingatkan suaminya pada sumpah yang pernah diucapkan Habibie ketika sakita parah dulu. Bunyi sumpah itu adalah: Terlentang!Jatuh! Perih! Kesal!/Ibu pertiwi/ Engkau pegangan/Dalam perjalanan/Janji pusaka dan Sakti/Tanah Tumpah darahku makmur dan suci/Hancur badan! Tetap berjalan!Jiwa besar dan suci!/Membawa aku padamu// Kata "padamu" menurut Habibie adalah Indonesia makmur dan suci yang mengandalkan pada keunggulan sumber daya manusianya (Habibie, 2010: 41-42). Habibie akhirnya lebih memilih bekerja di perusahaan kecil di Hamburg daripada bekerja di Boeing.Cinta telah menjadi penyala semangat nasionalisme dalam diri Habibie dan Ainun. Kesadaran akan posisi dan semangat untuk memajukan bangsa dengan tetap menjaga keutuhan keluarga itulah yang akhirnya mendorong Ainun untuk mengorbankan hobi dan pekerjaannya sebagai dokter.

Berdasarkan keyakinannya, Ainun mengorbankan hobi dan pekerjaannya sebagai dokter untuk membangun bersama Ilham, Tharieq, dan suaminya tetap menciptakan keluarga sakinah sesuai ajaran agama Islam dan budaya kami yang dikalbui oleh cinta yang murni, suci, sejati, sempurna, dan abadi. (Habibie, 2010: 62)

Nilai cinta, nasionalisme dan emansipasi tampak menonjol pada dua novel autobiografi yang ditulis oleh dua sastrawan perempuan, yaitu Fatimah (Hamidah) dan Soewarsih Djojopuspito, Kehilangan Mestika dan Manusia Bebas. Dalam sejarah sastra Indonesia Hamidah dan Soewarsih Djojopuspito dapat dikatakan sebagai perempuan yang mempelopori penulisan sastra Indonesia.Pada tahun 1935 novel pertama Hamidah, Kehilangan Mestika diterbitkan oleh Balai Pustaka. Tokoh utama novel tersebut Hamidah, persis nama pengarangnya. Dari data biografi pengarang, terungkap bahwa Hamidah adalah nama pena dari Fatimah. Sebelum diterbitkan dalam bahasa Indonesia dengan judul Manusia Bebas (1975) novel ini pertama kali ditulis dalam bahasa Belanda dengan judul Buiten Het Garrel (1940), dengan kata pengantar dari E. du Per- ron dan diterbitkan di Amsterdam atas bantuan dana dari Kerajaan Belanda.

Fatimah (Hamidah) lahir di Muntok, Pulau Bangka, Sumatra Selatan, 13 Juni 1915, dan di Palembang, 8 Mei 1953. Pendidikan terakhir Hamidah adalah Meisjes Normaal School (Sekolah Normal Putri) di Padang Panjang, Sumatra Barat. Setelah tamat dari Sekolah Normal Putri, dia kembali ke Muntok dan mengajar di Sekolah Rakyat (SR) Muntok, kemudian ia mengajar di Palembang Instituut mengambil mata pelajaran "Bahasa Inggris" dan "Pegang Buku". Hamidah gemar membaca karangan Shakespeare. Setelah itu, ia bekerja di perguruan Taman Siswa sampai Jepang datang. Saat revolusi berlangsung, ia membuka sekolah sendiri yang pada tahun 1949 diserahkan kepada pemerintah. Dia pernah menjadi pengurus P4A, Parnawi. Akhirnya, ia menjadi anggota Coerwis (diambil dari catatan dengan tulisan tangan yang tersimpan di PDS H.B. Jassin). Ia juga menjadi pembantu tetap Poedjangga Baroe di Palembang (http://ensiklopedia.kemdik-bud.go.id). Biografi ini mirip dengan kisah tokoh Hamidah dalam Kehilangan Mestika, sehingga dapat disimpulkan bahwa novel tersebut adalah sebuah autobiografi, seperti tampak pada kutipan berikut.

Karena ayah kami bukan seorang yang beradat kuno benar, dapatlah juga kami menduduki bangku sekolah, meskipun hanya sekolah Melayu Rendah saja, oleh sebab kami bukan orang yang mampu... (Hamidah, 1959:5).

Akan diriku bersama dengan seorang saudaraku yang lain, meneruskan pelajaran kami ke sekolah Normal Puteri di Padangpanjang. Tatkala akan meninggalkan ayah dan kampung halaman yang pertama kali, tambahan pula akan mengarungi lautan yang dalam dan lebar, timbullah kadang-kadang hati yang cemas. Mula-mula malaslah akan berangkat itu, meninggalkan segala yang dikasihi dikampung sendiri. Tetapi ayah yang ingin melihat anaknja menjadi orang yang berguna di kemudian hari untuk bangsa dan tanah air, 
menyuruh dengan tipu muslihat yang amat halus.(Hamidah, 1959:6).

Karena di negeriku akulah pertama sekali membuka pintu pingitan bagi gadis-gadis, maka bermacamlah cacian yang sampai ketelinga kaum keluargaku. Orang negeriku pada masa itu masih terlalu bodoh dan kuno... (Hamidah, 1959:22)

Dari novel Kehilangan Mestika tampak bahwa nilai emansipatoris pada diri Hamidah yang berbeda dengan perempuan lain di zamannya. Dia tidak hanya keluar dari tradisi pingitan untuk pergi ke sekolah, tetapi juga pergi me-rantau ke kota yang cukup jauh dari kampung halamannya untuk menempuh sekolah guru, Sekolah Normal Puteri di Padangpanjang. Sekolah Normal Putri (Normal School) adalah sekolah pendidikan guru pada masa kolonial Belanda (Gouda, 2007:171), sebuah sekolah yang memang dipersiapkan agar lulusannya bekerja sebagai guru. Dengan demikian, dengan memilih Sekolah Normal Putri untuk anak perempuan novel tersebut menawarkan gagasan yang membuka pintu bagi perempuan untuk memasuki lapangan kerja di sektor publik, yaitu sebagai seorang guru.

Dari novel Manusia Bebas kita dapat membaca nilai emansipasi, cinta, dan nasionalisme seorang perempuan bernama Sulastri, seorang guru Sekolah kebangsaan di Bandung yang harus berhadapan dengan tekanan pemerintah kolonial. Penulis novel Manusia Bebas, Soewarsih Djojopuspito adalah istri Soegondo Djojopuspito (tokoh pergerakan yang menjadi ketua Kongres Pemuda II) (Blackburn, ed., 2007:xxii). Soewarsih Djojopuspito menulis novelnya ketika suaminya, Soegondo Djojopuspito, menjadi pimpinan Sekolah Taman Siswa di Bandung (Poesponegoro \& Notosusanto, 2008:269). Adanya kemiripan biografinya dengan kisah yang ditulis dalam novelnya menunjukkan bahwa novel tersebut merupakan sebuah novel autobiografis.

Dalam Manusia Bebas Suwarsih memilih nama Sulastri untuk menggambarkan dirinya, sementara, nama suaminya Soegondo
Djojopuspito dalam novel bernama Sudomo. Keduanya harus berjuang menyelenggarakan Sekolah kebangsaan yang merupakan sekolah pribumi dan harus berhadapan dengan pemerintah kolonial. Mereka harus berhadapan dengan Ordonansi Sekolah Liar yang mengatur dan mengawasi keberadaan sekolah-sekolah swasta (Stuers, 2008:128). Akibatnya, banyak guru-guru yang karena memiliki semangat nasionalisme tinggi, nonkooperatif dengan pemerintah kolonial, dilarang mengajar seperti dialami oleh tokoh Sulastri dan suaminya, Sudarmo. Setelah dilarang mengajar, Sulastri mencoba menjadi seorang penulis novel. Perjuangan tersebut tampak pada kutipan berikut.

"Marti, Doakanlah aku dapat bekerja dengan penuh cita-cita. Kau masih ingat, bahwa persaudaraan antara kau dan aku harus mengekalkan kesetiaan kita akan sumpah kita berdua: bekerja bagi mereka yang tertindas dan untuk Indonesia, tanah air kita bersama.

Lastri. (Djojopuspito, 1975:18)

Dari kutipan tersebut kita dapat membaca nilai nasionalisme, selain emansipasi perempuan yang diperjuangkan Soewarsih melalui tokoh Sualstri. Judul Manusia Bebas pada novel tersebut secara metaforis mengacu kepada hasrat ingin merdeka yang dimiliki oleh tokoh-tokoh pribumi dalam berhadapan dengan kolonialisme Belanda. Di samping itu hal itu juga mengandung makna perlawanan kaum pribumi, termasuk kaum perempuan dalam berjuang melawan kolonialisme Belanda untuk menuju kemerdekaan Indonesia

\section{SIMPULAN}

Dari empat buah novel aoutobiografi yang dikaji ditemukan nilai kehidupan yang berkaitan dengan religiositas, cinta, nasionalisme, dan emansipasi. Nilai-nilai yang disampaikan tersebut menjadi visi para sastrawan dalam menjalani kehidupan dan proses kreatifnya, yang tentu tidak terlepas dari berbagai konteks sejarah, sosial, dan politik yang dinamis. Melalui novel autobiografi yang ditulisnya, seorang sastrawan suara batin, emosi, ide, bahkan juga 
ideologi yang dianutnya dalam menjalani hidupnya, bahkan juga visi ke depan yang dicita-citakan.

\section{DAFTAR PUSTAKA}

Azra, A. (2017). Surau: Pendidikan Islam Tradisional dalam Transisi dan Modernisasi. Jakarta: Pusat Pengkajian Islam dan Masyarakat (PPIM) UIN Syarif Hidayatullah.

Abrams, M.H. (1979). The Mirror and the Lamp, Romantic Theory and Critical Tradition. London, New York: Oxford University Press.

Djojopuspito, S. (1975). Manusia Bebas. Jakarta: Djambatan.

Habibie, B.J. (2010). Habibie-Ainun.Jakarta: THC Mandiri.

Hamidah. (1959). Kehilangan Mestika. Jakarta: Balai Pustaka. Cet. Ke-5.

Hamka. 2015a. Kenang-kenangan Hidup (jilid satu). Jakarta: Balai Pustaka.

Hamka. 2015b. Kenang-kenangan Hidup (jilid dua). Jakarta: Balai Pustaka.

Harjana, Andre. 1984. Kritik Sastra: Sebuah Pengantar. Jakarta :Gramedia.
Anderson, L. (2001). Autobiography: The New Critical Ideom. London and New York: Routledge.

Rush, James R. (2017). Adicerita Hamka: Visi Islam Sang Penulis Besar untuk Indonesia Modern. Jakarta: Gramedia.

Winslow, D. J. (1995). Life-Writing, A Glossary of Term in Biography, Autobigraphy, and Related Forms. Hawaii: University of Hawaii Press.

Wiyatmi.(2012). "Keterdidikan perempuan dan peran Perempuan dalam Masyarakat dalam Novel- novel Indonesia Periode 1920 - 2000-an." Disertasi. Program Studi Ilmu-ilmu Humaniora, Fakultas Ilmu Bidaya Universitas Gadjah Mada, Yogyakarta.

Wiyatmi. 2013. Menjadi Perempuan Terdidik, Novel Indonesia dan Feminisme. Yogyakarta: UNYPress.

http://ensiklopedia.kemdikbud.go.id/sastra/artikel/Hamidah|

Ensiklopedia Sastra Indonesia - Badan Pengembangan dan Pembinaan Bahasa, Kementerian Pendidikan dan Kebudayaan Republik Indonesia 